\title{
Leading With Compassion: A Story of Women Grassroots Leadership Amidst COVID-19 and Coastal Flooding ${ }^{1}$
}

\author{
Dias Prasongko ${ }^{2}$ and Wigke Capri ${ }^{3}$
}

Received: 10 September 2021 | Accepted: 19 October 2021 | Published: 30 November 2021

\begin{abstract}
This article elaborates on two important elements of women's leadership. First, it explores how leadership theory has abandoned its masculine perspective in favour of a "more feminine" one. The COVID-19 pandemic, a crisis that crippled the sociopolitical structure, has contributed to this shift. Second, the experiences of grassroots leaders who are active in the domestic sphere have begun to be considered, as has their increased activeness in the public sphere during the COVID19 pandemic. However, studies of women's leadership are highly elitist; such a paradigm is problematic, as it prioritises formal power structures and ignores the grassroots leaders who play a central role in maintaining the social order. This research finds that the pandemic has provided a valuable impetus not only for studies of formal elites but also women at the grassroots. Women have become highly powerful agents in the domestic sphere during the pandemic, and even expanded their agency into the public sphere. Women leaders have facilitated the implementation of government and community crisis response measures at the grassroots level.
\end{abstract}

Keywords: leadership, women, COVID-19, domestic sphere, agency

\footnotetext{
${ }^{1}$ This article was funded in part by the Australia Indonesia Centre and DFAT Australia through the "Impact of COVID-19 on Women's Access to Water, Sanitation and Hygiene in an Indonesian Fishing Village" project. For this project, Wigke Capri served as coordinator and grant recipient; Dias Prasongko acted as a researcher.

${ }^{2}$ Dias Prasongko is a researcher with the Research Centre for Politics and Government (PolGov) FISIPOL, Universitas Gadjah Mada.

${ }^{3}$ Wigke Capri is a lecturer and researcher at the Department of Politics and Government, Universitas Gadjah Mada
} 


\section{Introduction}

The dominant narrative that prioritises male leadership has strongly influenced leadership theory, with its concepts, terminology, actions closely associated with men. Masculine biases permeate the knowledge structures and institutional practices of society. This dominance is clearly reflected in various studies and historical records that emphasise the importance of men as kings, military commanders, politicians, and scientists. As such, it is not surprising that leadership has commonly been identified with masculinity, with terms such as "great man" and "big man" (Stogdill, 1948; Rost, 1991; Northouse, 2004). However, over time, the idea of exclusively masculine leadership has slowly been disrupted. A series of crises have contributed to this disruption, including in the theorisation, conceptualisation, and practice of leadership. The idea that leaders must be assertive, aggressive, authoritative, and even muscular has given way to the idea that leaders must be empathetic, caring, and compassionate, willing to listen to others and heed their advice.

The latest report from the InterParliamentary Union (2021) indicates that, in 2020 , women accounted for $25.5 \%$ of legislators around the world-the highest since the organisation published its first report. In the past two years, academic studies into leadership, women, and gender have increased significantly. A search of journal articles published between 2018

${ }^{4} \mathrm{~A}$ search of SCOPUS-indexed journal articles using the keywords "gender", "women", and "leadership" returned 527 articles from 108 journals for 2018. This had increased to 635 articles by 2020 . and 2020 found that the number of indexed articles on gender, women, and leadership increased fourfold. ${ }^{4}$ According to Google Scholar, for example, approximately 49,0000 articles with these themes were published during this period. ${ }^{5}$

Women leaders and their role in the public sphere have likewise drawn increased public attention. Several, such as Angela Merkel in Germany and Jacinda Adern in New Zealand, have become the highest elected officials in their government. During the COVID-19 pandemic, women leaders have been praised for developing appropriate and well-targeted policies for mitigating the pandemic and its effects. Reviewing data on infection and mortality rates in 144 countries worldwide, Abras, Fava, and Kuwahara (2021) found that the nineteen countries led by women generally had fewer cases and deaths per million people than countries led by men.

In Indonesia, women have played a relatively prominent political and economic role, as reflected in the appointment of President Megawati Soekarno Putri, Minister of Finance Sri Mulyani, and Minister of Foreign Affairs Retno Marsudi. Nevertheless, discourses regarding women's leadership have been limited to formal political and economic leaders: heads of government, corporate presidents, and directors of international organisations (Aldrich, \& Lotito, 2020; Johnson, \& Williams, 2020; Sojo, Wood, Wood, \& Wheeler, 2016).

\footnotetext{
${ }^{5}$ A search was conducted through Google Scholar using the keywords "gender", "women", and "leadership". Results were filtered to only return items published between 2018 and 2020.
} 
In practice, the majority of leadership positions are occupied by men. In Indonesia, for example, women accounted for only $22 \%$ of the House of Representatives' 575 members after the 2019 election; this represented only a one per cent increase over the 2014 election. Following Indonesia's simultaneous elections in 2018 , only $9.06 \%$ of Indonesia's 342 local leaders were women; the previous year, it had been $5.90 \%$.

A study by Esarey and Chirillo (2013) found that women leaders tend to enjoy a better reputation than male leaders, including higher levels of public trust and lower levels of corruption. Women leaders likewise issue different public policies than their male peers. Although various studies have shown that women leaders are no less effective, their lack of formal representation remains a major challenge.

Women's leadership was widely discussed when the financial crisis erupted in 2008. The year prior, McKinsey and Company (2007) published an interesting study of 89 European corporations that found that companies that involved more women in their leadership tended to perform better than companies that did not. After the crisis, a plethora of studies asked the same question: would the collapse of the Lehman Brothers have occurred had the same company been the Lehman Sisters? (Kristof 2009; Lagarde 2010; Morris 2009; van Staveren, 2014). In subsequent years, countries around the world began replacing their male bank executives with women. As noted by van Staveren (2014), women have become the leaders of the Central Bank of Spain, the Central Bank of Iceland, the Securities and Exchange Commission and the Federal Bank of the United States, and the
International Monetary Fund (van Staveren, 2014).

As with the financial crisis of 2008 and the Southeast Asian monetary crisis of 1997-1998, the COVID-19 pandemic has created new spaces for women leaders. Academic and popular discourses have regularly highlighted women's role in pandemic mitigation. The COVID-19 pandemic has been more than a health crisis; it has had a domino effect on economies and political systems worldwide. In Indonesia, 137,156 deaths have been attributed to COVID-19 since it was first detected in the country in March 2020 (Our World in Data, 2021). It has also had a detrimental effect on the national economy; a report by Statistics Indonesia (2021) notes that, in 2020, the Indonesian economy experienced negative growth of $2.07 \%$. During the same period, the unemployment rate increased to $7.07 \%$; in other words, 9.77 working-age Indonesians were unemployed. Employers throughout the country also cut back on their employees' hours (Statistics Indonesia, 2021).

Johnson and William (2020) write that, due to the COVID-19 pandemic, previously male-dominated spaces have been made open to women. A study conducted by Abras, Fava, and Kuwahara (2021) found that, between January and July 2020, infection and death rates were lowest in the nineteen countries led by women: Belgium, Bangladesh, Bolivia, Switzerland, Germany, Denmark, Estonia, Ethiopia, Finland, Georgia, Greece, Iceland, Norway, Nepal, New Zealand, Singapore, Serbia, Slovakia, and Trinidad and Tobago.

The success of these women leaders has drawn significant media and academic attention (Aldrich \& Lotito, 2020; Freizer et 
al., 2020; Windsor et al., 2020; Zenger \& Folkman, 2020). Discourses have focused on women's leadership styles, which differ significantly from those of men: women leaders tend to lead with love, to listen to others and heed their advice. As such, they are better prepared for risk management. Studies by Aldrich and Lotito (2020) and Windsor et al. (2020) concur that women leaders are capable of embracing their femininity while simultaneously dealing with public expectations.

This article explores two important aspects of women's leadership. First, it explores how leadership is being redefined, with masculine biases giving way to understandings that accept feminine approaches. Although other political contexts have influenced this shift, the current crisis and its socio-political effects have been major drivers of the redefinition of leadership. Femininity, rather than being associated with weakness, has become seen as strength. Where women were previously precluded from leadership due to prejudice, in recent years there has been increased emphasis on empathy, compassion, and willingness to accept feedback from others-all of which are foundational for risk management.

Second, focus has shifted away from formal leadership in recent years, with many scholars instead looking to the grassroots leaders who are active primarily in the domestic sphere. Such writers view the traits employed by women elites as being "borrowed" from their everyday domestic lives: in the domestic sphere, women are often involved in communal activities; use compassion to manage their households; listen carefully to others; practice fiscal management; and minimise risks to their families and communities.
To realise these goals, this article uses the case study method to reveal the reality of women's leadership at the grassroots level. This method was chosen because it was best suited to unique geographic conditions, social structure, and interpersonal interactions of the location, and thus most capable of obtaining a descriptive and analytical understanding of the phenomenon under investigation. For this purpose, data were collected through interviews and focus group discussions (FGDs) with twenty-five women and five men in Tambak Lorok, North Semarang District, Central Java. Both interviews and FGDs were facilitated by technology, including the digital platforms WhatsApp and Zoom. The authors also asked the participants to submit their everyday experiences, pictures, and videos. This community was chosen because its members experienced two crises simultaneously: tidal flooding and the COVID-19 pandemic. As such, the pandemic has exacerbated their already difficult situation.

At the community level, women's leadership facilitates the effective and efficient implementation of public policies even as it promotes the welfare and health of the community. Taking the COVID-19 pandemic as its context, this study investigates how women have taken a central role in the ongoing crisis and elucidates their leadership experiences.

Tambak Lorok is located in northern Semarang, along the northern coast of Java. As a coastal community, it frequently experiences tidal flooding, which is known locally as rob. Before the COVID-19 pandemic, men mostly worked as fishermen, factory workers, and labourers, while women often sold goods to 
supplement their families' incomes. Both men and women were involved in diverse social, economic, and political activities. However, following the closure of factories and other places of employment due to the pandemic, women became their families' main providers.

As COVID-19 continued, several "women activists" took control to ensure the stability and welfare of their community, becoming agents who introduced community members to mitigation protocols and promoted the implementation of these measures as a means of curbing the spread of COVID-19. Women's involvement in this process marked their emergence as leaders in a time of economic instability. To better understand this process, this article seeks to expand the understanding of leadership by showing how women are involved in and contribute to their community.

\section{The Old Story of Male Leadership}

For decades, studies in such fields as management, psychology, and business have sought to conceptualise and define leadership. However, academics have yet to agree upon a shared definition (Bass \& Stogdill, 1990; Winston \& Patterson, 2006, Silva, 2014). Studies of leadership have understood it diversely, from the biological and genetic (Johnson, Vernon, \& McCarthy, et al., 1998) to the behavioural, from something inherent to particular characters and personalities (Larsson \& Vinberg, 2010) to something that can be learned (Murphy, Elliott, Goldring, \& Porter, 2007). More recently, studies have offered alternative models of leadership.

Many concepts of leadership have been proposed over the past century. For ease of discussion, the authors propose four categories: great man theories, behaviouralist theories, transactionalist/transformationalist theories, and feminist leadership theories.

Theories that explicitly associate leadership with men fall under the first category (Stogdill, 1948; Rost, 1991; Northouse, 2004). Such theories understand leadership as something special, inherent to individual men, and passed hereditarily (Zaccaro 2007). As it is hereditary, it cannot be possessed by simply anyone. Thomas Carlyle was a major proponent of this theory, which he advanced through his studies of the heroism and heroic worship associated with important leaders. Such individuals have something special that distinguishes them from their followers (Van Wart, 2003; Bass \& Stogdill, 1990; Judge, Ilies, Bono \& Gerhardt, 2002). According to Jogulu and Wood (2006), men are prioritised in such theories, as they are the ones who have wielded the greatest social, political, and economic power.

The authors hold that "great" or "big man" theories are problematic as they draw exclusively on the social and political paradigms of the Global North. Although these theories are built on different assumptions and realities than found in the Global South (where matriarchal societies are more common), they have nevertheless influenced how leadership is understood in southern nations.

Behaviouralism contrasts sharply with the "great" or "big man" theories, as it describes leadership not as inherent to specific individuals, but as a learned behaviour (Farahbaksh, 2007). It discusses leadership as derived not from specific character archetypes, but rather as 
something observed and ultimately learned. This theory holds that, to become a leader, one must behave in accordance with a specific set of guidelines. As such, one can receive leadership training or participate in programs designed to promote leadership behaviours. Many mainstream theories on leadership are built upon the foundation laid by behaviouralism.

Owing to the paucity of women leaders in the United States during its development, this theory was biased in favour of male leadership styles. However, in recent years it has recognised and accommodated the stylistic differences between men and women leaders. Hearn and Parkin (1986: 38) found that the adjectives used to describe leaders ("competitive", "aggressive", "dominant") are commonly associated with men. Similarly, women who occupy leadership positions are often described with terms that connote masculinity. A doctoral thesis prepared by Taylor (1973) contrasted the distinct characteristics of male and female leadership, finding that men tend to be oriented more towards direct leadership while women are more skilled with administrative matters. Interestingly, Taylor noted that respondents (most of whom were men) expressed a desire for more women leaders in the education sector.

More recently, the theories of transactionalism and transformationalism have focused not on individual leaders and their particular behaviours and styles (as "great"/"big man" and behaviouralist theories) but more general characteristics. According to Bass (1990), transactional leadership is marked by two factors: workplace organisation and a focus on those persons who perform best.

Transactional leaders often rely on rewards and punishments to incentive improved performance. Leader promise an exchange: those who perform best and create results will be rewarded, as will those who loyally follow their leader (Goethals \& Hoyt, 2016: xi). Such a model, however, is not always effective, and it may indeed be counterproductive; transactionalism relies heavily on leaders' continued control of resources, with which they can reward their followers (Bass, 1999: 21; Bass \& Bass, 2008; Kuhnert \& Lewis, 1987: 649). Often, rewards are beyond the purview of leaders; wages and promotions, for example, depend not on leaders' whims but individual qualifications, organisational guidelines, and seniority.

Transformative leadership, meanwhile, refers to a model wherein leaders actively urge their followers to participate in diverse processes (Goethals \& Hoyt, 2016: xi). It is marked by the ability to direct others and accommodate their interests, thereby ensuring that they are willing to work towards social transformation (Bass, 1990). Efficiency is important, as only then can collective goals and social transformations be realised (Burns, 1978, in Stewart, 2006). According to Bass (1990), although transformative leadership often relies heavily on charisma, it also calls for intellectual stimulation and rational problem-solving.

Burns (in Stewart, 2006) writes that transformative leadership emerged in response to the excessive emphasis on power in leadership. In reality, leaders not only wield authority, but also act as agents of public morality (Burns, 1978, in Bass \& Bass, 2008). Leaders must thus cultivate 
the potential of those they lead while simultaneously ensuring that their individual needs are met and public spaces are open to their participation.

Bass (1990) clearly distinguishes
transactional and
transformational leadership. According to
Bass, transformative leadership is marked
by charisma, inspiration, intellectual
stimulation, and individual consideration.
Conversely, transactional leadership is
marked by contingent rewards,
management by active exception, and
management by passive exception, and a
laissez-faire approach to decision-making.

\section{Moving Beyond Male-Biased Leadership: A Feminine Way of Leadership}

Alternative approaches to leadership have emerged in response to traditional leadership's failure to realise true social change. Traditional models of leadership centre on individual leaders and their ability to "lead from the front" (as well as organisational culture and leadership styles), while alternative models emphasise the ability to mobilise and inspire (Bennis, 2009, in Martin, 2018; Avant, 2011). According to Latham (2014), the shift away from traditional leadership has also been driven by the significant gap between the theory of leadership and its actual practice, as well as the differences between the perspectives of academics and practitioners/consultants.

Underpinning alternative and nontraditional views of leadership are feminist understandings of gender. Alternative models of leadership seek to promote equality, ensuring that women have the space to represent themselves by becoming leaders. Many prominent women leaders have emerged in recent years, including in the fields of politics, economics, and education (Carli \& Eagly, 2001; UN Women, 2021, Catalyst, 2020; Hinchlifee, 2021). Nevertheless, it cannot be denied that women leaders continue to be doubted. They face discrimination and stereotyping, and are even frequently compared unfavourably to male leaders, even though they must balance their careers with their family/domestic lives (Levitt, 2010; Goethals \& Hoyt, 2016, Eagly \& Heilman, 2016).

In recent years, leadership theories have been challenged to integrate the feminine aspects of leadership that have long been neglected (Valentine, 1992; Jogulu et al, 2006; Chin, 2004, Brown \& Irby, 1994; Duffy \& Trautman, 2002). Beverly J. Irby (2002), reviewing 24 leadership theories, found that women's experiences have frequently been excluded from leadership theories. Instead, women are frequently positioned as objects when theories are implemented and modelled. According to Eagly, Wood, and Diekman (2000), this situation is reflected in the theory of social roles developed by Alice $\mathrm{H}$. Eagly in 1987, wherein women were identified as part of the "community" rather than individual agents with the ability to make their own decisions. Women are associated with warmth and compassion, and thus with interpersonal relations; men, conversely, are associated with individual strength and assertiveness. It is these individual qualities that have long been associated with leadership (Cejka \& Eagly, 1999).

An alternative understanding of leadership, rooted in the extensive debate between femininity and masculinity (i.e. gender stereotypes), was offered by 
Gutierrez and Lewis (1995). They note that, according to feminist leadership theory, it is important for leaders to act holistically. They must not make their decisions based on gender stereotypes, as such stereotypes tend to ignore the diversities of gender. Lorraine M. Gutiérrez and Edith Lewis identified feminist leadership as having six main characteristics:

1. Recognising the importance of using a gender perspective to understand issues and find solutions.

2. Recognising the importance of listening to others and empowering women to resolve their own issues.

3. For empowerment, it is best to cultivate a shared awareness of the importance of including others and accommodating their diverse roles.

4. The personal is political: leadership styles and community administration must employ a bottom-up approach.

5. Feminist theory must be built upon the belief that "diversity is power". It must thus recognise such diverse factors as age, generation, race, skin colour, social class, ability, education, talent, and sexual orientation.

6. Feminist theory must employ a holistic approach, one that recognises the emotional, spiritual, physical, environmental, creative, and intellectual as essential for working with women.

While Gutierrez and Lewis ascribed a holistic approach to feminist leadership, Helgesen (1995) understood it as relying on a "web of inclusion". Helgesen emphasised the importance of conceptualising leadership not as a hierarchy, but as a "web" of communication systems. Helgesen writes that both men and women may be involved in their communities.

Chin (2004) writes that feminist leadership is characterised by a collaborative effort to realise an egalitarian society. Leadership is not individual, but shared. Meanwhile, Raelin (2003) described feminist leadership as a dynamic approach to leadership that is built upon the foundation of community and compassion. Raelin identified "four C's" of leadership practices: concurrent, collective, collaborative and compassionate.

This study understands women leaders as having distinct styles and concerns, which differ from those of male leaders. To cite De La Rey (2005), alternative/feminist leaders are aware of gender and its influence on morality. They tend to be more open, participative, communicative, and willing to involve others in realising collective goals (Goethals \& Hoyt, 2016; Carli \& Eagly, 2011, in Goethals \& Hoyt, 2016).

In this study, leadership is understood not as a purely individual or inherited quality. Leadership emerges through social processes that distribute power within the community (De La Rey, 2005). It is a social process that creates spaces in which all persons may actively participate in discourse and dialogue. As such, leadership serves not simply to achieve the goals of the individual, but to transform the individual interests into collective ones.

\section{Looking Closer at the Grassroots}

The effects of the COVID-19 pandemic have been felt in diverse sectors. For the residents of Tambak Lorok, the pandemic has had significant health and 
economic consequences. Along with waste, the tidal flooding experienced by the community brings bacteria and disease, which can exacerbate the health effects of COVID-19. At the same time, the pandemic has caused a significant slowdown in the economy. Stay-at-home orders have limited fishermen's ability to sail, while factories and other employers have dismissed much of their workforce. For the residents of Tambak Lorok, the crisis is not a global or national one; it is close to home, affecting their families, friends, and neighbours.

Of the twenty-five women and five men interviewed, $97 \%$ had lost their main source of income. Interviews indicated that $98 \%$ of respondents lived in households where the man was the main breadwinner; the remaining $2 \%$ of respondents were single mothers. As men lost their livelihoods during their pandemic, women thus sought alternative sources of income (often informal ones) to ensure their families' continued wellbeing. By trading wares and operating kiosks, women became their families' main source of income. This transformed the dynamics of their families, and this enabled women to take on leadership roles. The extent of this leadership varied between families:

"My husband can't go to sea, so I am the one earning money for food, cleaning shells and whatnot. For a kilogram, I can get Rp 2,500. But yeah, I don't only get one kilogram; every day, I take at least Rp 25,000 home." ( $N$, woman, 2 September 2020).

"I happened to already have a shop, a variety store left by my parents. So since my husband's company went bankrupt during the pandemic, I've spent my time working that shop." (W, woman, 3 September 2020).

"I normally earn supplemental income at home by washing clothes, running a laundromat. But now, during the pandemic, few people send their clothes to me for washing. So I sell what I can, cakes and whatnot. If I succeed, well that is good. My husband, he isn't working... he was fired in March 2020. Now he stays at home, not sure what kind of work he wants." (Wt, woman, 4 September 2020)

The women identified as N, W, and Wt are three of the eighteen women who earn less than $\mathrm{Rp} 500,000$ per month. Of the twenty-five women informants, twenty-four had had some form of income before the pandemic. After the pandemic, however, they were the ones who had to ensure their families' continued survival. As such, they became their families' main breadwinners, and thus took on an important leadership role.

On average, women informants earned less than $\mathrm{Rp} 17,000$ per day. They attempted to save this money, even as they paid for their families' everyday expenses. They were the ones who bought rice, paid for water, and purchased the cellular data that their children needed for online schooling.

"No matter what, my children need to eat, go to school, because now they need internet data, right?" (N, 2 September 2020)

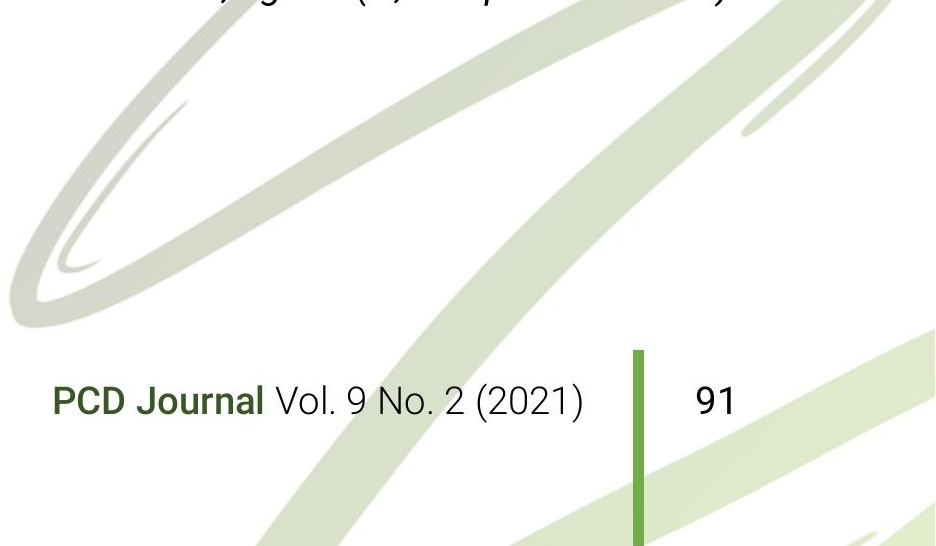


To support her family, S promoted her husband's furniture during communal activities.

"My husband, see, works with furniture, selling furniture. Our income dried up between March and June, because nobody was buying furniture. Normally, my husband could pull in some Rp 10 million per month. During the pandemic, Alhamdulillah we've still been able to pull in Rp 750,000. Yeah, I don't work, but I manage the money. So the other day, when I participated in a Community Welfare program in a neighbouring village, I tried to sell my husband's wares." (S, woman, 4 September 2020)

For $\mathrm{S}$, the pandemic was a time to take control of the household. As her husband's furniture orders dried up, she began searching for new customers. S saw an opportunity to sell new products to new customers, who would be willing to purchase her husband's relatively inexpensive furniture. To incentivise customers and increase sales, she also began offering an instalment plan; this had the additional benefit of providing her with a continuous income stream.

As women have taken on leadership roles by becoming their families' main breadwinners, their compassion has enabled them to avoid feeling burdened by their situation. They see their new leadership roles as manifestations of their love for their husbands and children, taken to ensure their continued survival.

Such resilience was not found amongst the five men interviewed in Tambak Lorok, nor most informants' testimonials regarding their husbands.
Male residents have felt significant mental burdens due to the social construct that "forces" men to act as leaders and associates their masculinity with their ability to provide for their families. Many men spend their time outside the home; they find it difficult to witness their wives' continued efforts to support their families, as they feel that they have failed as providers.

"I haven't gone to sea for four months now. Yeah, if I don't go to sea, I can't sell any fish, and it's difficult. The money at home, my wife earns it. Me, I'm confused about what I should do. I can't give her any money, so I just wander about." ( $A$, man, 8 September 2020).

Also important during the pandemic have been efforts to distance families from the threat of COVID-19. Women have been at the vanguard, protecting their families by ensuring that masks, hand washing facilities, and hand sanitiser are available; washing their families' laundry; and providing clean water. Due to tidal flooding, the latter has been particularly difficult.

"So, every day, when we wake up, there's another flood. So I have to cook, iron the clothes, and after the flooding has subsided, I clean the house. The tidal waters are dirty, right... they sometimes bring garbage and whatnot into the house. If we're lucky, it'll bring the yellow [human feces] with it. After the floods, we can't use our washrooms, and so we can only clean after the water subsides. Only once things are clean can I take care of other things." ( $N$, woman, 6 September 2020) 
The tidal flooding that affects Tambak Lorok every morning has significantly affected the community's responses. In the evening, residents take action to anticipate the morning flood. They park their motorcycles on high ground, mostly near the market, and secure their belongings in the highest parts of their homes.

Many studies have highlighted how the pandemic has imposed additional burdens on women. The residents of Tambak Lorok who earn less than Rp. 500,000 per month lack the financial resources necessary to purchase masks (be they medical-grade or cotton). One informant, W, made masks for her family. However, she has been unable to supplement her income by selling these masks at the market; due to the difficult economic situation, residents are unwilling to purchase items that they can make themselves.

"Masks, I make them myself from fabric. I've never bought medical-grade masks. Once, I got some from the Red Cross, but afterwards I made masks from scrabs and unused clothes. If my husband leaves the house, I remind him to wear his mask. My children too". (Wt, woman, 6 September 2020).

The sluggish economy also limited residents' ability to access hand sanitiser and clean water. Bottled drinks and hand sanitiser became luxuries, and thus appropriate souvenirs. Women showed their compassion by highlighting the joy they felt at seeing their families' reactions.

"Wah, I'm happy when I receive hand sanitiser and masks from community activities. As take-homes, you see. Oh, I also bring home bottled drinks for my children, take-homes for them too."

In "great" and "big man" theories of leadership, women are understood as community-minded, and thus lack the agency of individualistic male leaders. In feminist theories of leadership, meanwhile, women are understood as practising shared leadership within a "web of inclusion".

Women not only took leadership roles within their families, but also within their community. With their peers, they worked to overcome tidal flooding and the pandemic, serving as the vanguard of pandemic mitigation measures. Women greatly facilitated efforts to protect their community from COVID-19. Women were the main drivers of health protocol implementation, as they identified themselves as ensuring the continued wellbeing of their families. They promoted masking, hand washing, routine exercise, and proper nutrition as means of buttressing the immune system. Through such activities, women ultimately advanced not only the welfare of their families, but also that of their community.

Women's exemplary leadership role can be attributed to their health knowledge, which tends to be superior to that of men. Most of the women interviewed viewed themselves as "health agents", as they were actively involved in promoting government programs. Many of them had previous experience in programmes designed to promote maternal and paediatric health, such as the Integrated Service Post and 
stunting prevention programmes. It is thus not surprising that these women were concerned not only for the well-being of their families, but also the broader community. Conversely, men tended to focus on their own problems and their jobs.

For example, $\mathrm{T}$ acted not only as the backbone of her family of five-her three children and husband-but also as a community activist involved in the Integrated Service Post programme as well as the local fishermen's association, political group, and administrative mobilisation team. She is thus acknowledged by her community as a woman who has used her interpersonal communications to promote the betterment of the community, both through social and political activities.

During the pandemic, $T$ actively promoted adherence to governmentimplemented health protocols. She even worked together with the sub-district and district government, going door-to-door to promote health protocols designed to mitigate the spread of COVID-19. Working together with $\mathrm{L}$ and $\mathrm{W}, \mathrm{T}$ also distributed supplies that had been provided to the community by government and private actors. One of these women, L, submitted a photograph showing that the Integrated Service Post programme had continued. The women were observing proper health protocols, and wearing boots to avoid the floodwaters.

Women's communicative and persuasive abilities were foundational for their efforts to promote proper health protocols amongst the people of Tambak Lorok. Domestic values were expanded into the community through women's particular approach to leadership. In so doing, the public interest was advanced.
Through their particular activities, women showed that they were capable of managing public affairs even in times of crisis. To promote proper health during the COVID-19 pandemic, women transformed individual practices into community ones, thereby facilitating the realisation of shared goals. The respect enjoyed by these women facilitated their efforts to promote shared values within the community.

At the same time, women exhibited the value of care commonly associated with feminine leadership. Both their economic activities and social activities departed from the principle of care, having been designed to ensure the wellbeing of their families and their communities. In the face of continued stereotyping, women employed the principle of care to advance the community's interests during the COVID-19 pandemic. Feminine values were thus inexorably intertwined with women's efforts to collaboratively promote the betterment of the community.

\section{Conclusion}

Leadership has long been understood as hierarchal, both in malebiased and feminine leadership theories. Although it has been hoped that feminist theories of leadership would embrace people of all races, skin colours, ages, and social classes, in practice studies using such theories have continued to focus on elite women. It is thus necessary to reexamine the concept of leadership and recognise the importance of domestic leadership at the grassroots.

At the grassroots, women's leadership abilities have enabled them to maintain solidarity within their families and communities during the ongoing COVID-19 
pandemic. Women's leadership has provided them with an important means of upholding the social construct, one that requires further examination. At the same time, it is important to further investigate the effect of the ongoing crisis on the leadership, mental health, and masculinity of men. 


\section{References}

Avant, D. W. (2011). Unwrapping tradition: Shifting from traditional leadership to transformative action. Counterpoints, 409, 114-127.

Avolio, B. J. (2005). Leadership development in balance: made/born. New Jersey: Lawrence Erlbaum Associates.

Statistics Indonesia. (2021, 9 September). Berita resmi statistik (BRS): Ekonomi Indonesia 2020 turun sebesar 2,07 persen kumulatif (c-to-c). https://www.bps.go.id/pressrelease/2021/02/05/1811/ekonomi-indonesia-2020turun-sebesar-2-07-persen--c-to-c-.html.

Statistics Indonesia. (2021, 9 September). Berita Resmi Statistik (BRS). Februari 2021: Tingkat pengangguran terbuka (TPT) sebesar 6,26 persen. https://www.bps.go.id/pressrelease/2021/05/05/1815/februari-2021--tingkatpengangguran-terbuka--tpt--sebesar-6-26-persen.html.

Barker, R. A. (2002). On the nature of leadership. Lanham: University Press of America.

Barnard, J. W. (2007). More women on corporate boards? Not so fast. William \& Mary Journal of Women and the Law, 13(3): 703-726.

Barnett, R. C. (2002). A new look at old theories: New times call for new views. Women's Studies Research Centre, Brandeis University. http://www.brandeis.edu/centers/cfwp/barnett_presentations/Theory.ppt. Accessed 2 September 2008.

Barnett, R. C., \& Shibley, H.J. (2001). Women, men, work, and family: An expansionist theory. American Psychologist, 56(10): 781-796. DOI: 10.1037//0003-066x.56.10.781.

Barrick, M. R., Day, D.V., Lord, R.G., \& Alexander, R.A. (1991). Assessing the utility of executive leadership. Leadership Quarterly, 2(1): 9-22. DOI: 10.1016/1048-9843(91)90004-L.

Bartol, K., \& Martin, D. (1986). Women and men in task groups. In R. Ashmore \& F. Del Boca (eds.), The social psychology of male-female relations: a critical analysis of central concepts (pp. 259-310). Orlando, FL: Academic Press.

Barton, T. R. (2005). Leadership constructions of the past, present and future: in search of a better model (a feminist model). Paper presented at the seminar "In Search of My Mother's Garden, I Found My Own: Celebrating the Past, Honoring the Present, and Preparing for the Future". Wright State University, Dayton, Ohio.

Bass, B. M. (1990). From transactional to transformational leadership: Learning to share the vision. Organizational Dynamics, 18(3), 19-31. DOI: 10.1016/0090-2616(90)90061-S.

Bass, B. M. (1985). Leadership and performance: beyond expectations. New York: Free Press.

Bass, B. M., \& Avolio, B.J. (1990). Transformational leadership development: manual for the multifactor leadership questionnaire. Palo Alto, CA: Consulting Psychologists Press.

Bass, B. M., \& Avolio, B.J. (1994). Shatter the glass ceiling: women may make better managers. Human Resource Management, 33(4): 549-561. 
Bass, B. M., \& Avolio, B.J. (2000). Multifactor leadership questionnaire: technical report. Redwood City, CA: Mind Garden.

Bass, B. M., \& Bass, R. (2008). The Bass handbook of leadership: theory, research, and managerial applications (4th ed.). New York: The Free Press

Bass, B. M., \& Stogdill, R. M. (1990). Bass and Stogdill's handbook of leadership (3rd ed.). New York: Free Press

Carli, L. L., \& Eagly, A. H. (2001). Gender, hierarchy, and leadership: An introduction. Journal of Social Issues, 57, 629-636. DOI: 10.1111/0022-4537.00232.

Catalyst. (2020, 23 January). Quick take: women in academia. Retrieved from https://www.catalyst.org/research/women-in-academia/.

De La Rey, C. (2005). Gender, women and leadership. Agenda, 19(65): 4-11.

Eagly, A. H., \& Heilman, M. E. (2016). Gender and leadership: introduction to the special issue. The Leadership Quarterly, 27, 349-353. DOI: 10.1016/j.leaqua.2016.04.002.

Goethals, G. R., \& Hoyt, C. L. (eds.). (2016). Women and leadership: History, theories, and case studies. Great Barrington, MA: Berkshire Publishing Group.

Ritchie, H., Mathieu, E., Rodés-Guirao, L., Appel, C., Giattino, C., Ortiz-Ospina, E., Hasell, J., Macdonald, B., Beltekian, D. \& Roser, M. (2020). "Coronavirus Pandemic (COVID-19)". OurWorldInData.org. Retrieved 9 September 2021 from: https://ourworldindata.org/coronavirus.

Hinchlifee, E. (2021, 8 September). The female CEOs on this year's Fortune 500 just broke three all-time records. Fortune. Retrieved from https://fortune.com/2021/06/02/female-ceosfortune-500-2021-women-ceo-list-roz-brewer-walgreens-karen-lynch-cvs-thasundabrown-duckett-tiaa/

Johnson, A. M., Vernon, P. A., McCarthy, J. M., Molson, M., Harris, J. A., \& Jang, K. L. (1998). Nature vs nurture: Are leaders born or made? A behavior genetic investigation of leadership style. Twin Research and Human Genetics, 1(4): 216-223. DOI: $10.1375 / 136905298320566195$.

Kuhnert, K. W., \& Lewis, P. (1987). Transactional and transformational leadership: A constructive/developmental analysis. Academy of Management Review, 12(4): 648-657. DOI: $10.2307 / 258070$.

Larsson, J., \& Vinberg, S. (2010). Leadership behaviour in successful organisations: Universal or situation-dependent?. Total Quality Management, 21(3): 317-334. DOI: 10.1080/14783360903561779.

Latham, J. R. (2014). Leadership for quality and innovation: Challenges, theories, and a framework for future research. Quality Management Journal, 21(1): 11-15.

Levitt, D. H. (2010). Women and leadership: a developmental paradox? Adultspan Journal, 9(2): $66-75$. 
Martin, W. (2018). Leadership: outdated theories and emerging non-traditional leadership. Doctoral dissertation, Northcentral University.

Murphy, J., Elliott, S. N., Goldring, E., \& Porter, A. C. (2007). Leadership for learning: A researchbased model and taxonomy of behaviors. School Leadership and Management, 27(2): 179-201. DOI: $10.1080 / 13632430701237420$.

Rost, J. C. (ed.). (1993). Leadership for the twenty-first century. Westport, CT: Praeger.

Silva, A. (2014). What do we really know about leadership?. Journal of Business Studies Quarterly, 5(4), 1. DOI: 10.1037/1089-2680.9.2.169.

Sinclair, A. (1994). Trials at the top: chief executives talk about men, women and the Australian executive culture. Melbourne: The Australian Centre, The University of Melbourne.

Sinclair, A. (1995). Sex and the MBA. Organisation, 2(2): 295-317.

Sinclair, A. (1997). The MBA through women's eyes: learning and pedagogy in management education. Management Learning, 28(3): 313-330.

Sinclair, A. (1998). Doing leadership differently: gender, power and sexuality in a changing business culture. Carlton South, Victoria: Melbourne University Press.

Sinclair, A. (2000). Teaching managers about masculinities: are you kidding? Management Learning, 31(1): 83-101.

Sinclair, A. (2001). Body and pedagogy. Paper presented the Gender, Work and Organisation Conference, Keele, United Kingdom.

Sinclair, A. (2004). Journey around leadership. Discourse: Studies in the Cultural Politics of Leadership, 25(1): 7-19

Sinclair, A. (2005). Working Paper: Journey around leadership. Melbourne: Melbourne Business School. 10.1080/0159630042000178455.

Sinclair, A. (2006). Challenging leadership myths and building community leadership. Paper presented at the Communities in Control Conference, Melbourne.

Sinclair, A., \& Wilson, V. (2002). New faces of leadership. Carlton: Victoria: Melbourne University Publishing.

Smith, D. (1987). The everyday world as problematic: a feminist sociology. Milton Keynes: Open University Press.

Smith, M. L. (1987). Publishing qualitative research. American Educational Research Journal, 24(2): 173-183. DOI: $10.2307 / 1162889$.

Sojo, V. E., Wood, R. E., Wood, S. A. \& Wheeler, M. A. (2016). Reporting requirements, targets, and quotas for women in leadership. Leadership Quarterly, 27(3): 519-536. DOI: 10.1016/j.leaqua.2015.12.003.

Spender, D. (1985). For the record: the making and meaning of feminist knowledge. London: The Women's Press Limited. 
Spivak, G. 1989. Feminism and critical theory. In D. Latimer (ed.), Contemporary Critical Theory (pp. 634-658). San Diego: Harcourt Brace Jovanovich.

Spradley, J. P. (1979). The ethnographic interview. London: Holt, Rinehart \& Winston.

Squire, S., \& Tilly, J. (2007). It's about time: women, men, work and family, final paper 2007. Human Rights and Equal Opportunity Commission of Australia: HREOC

Stanley, L. (1997). Knowing feminisms: on academic borders, territories and tribes. London: Sage.

Stanley, L., \& Wise, S. (1979). Feminist research, feminist consciousness and experiences of sexism. Women's Studies International Quarterly, 2(3): 359-374. DOI: 10.1016/S01480685(79)91580-X.

Stanley, L., \& Wise, S. (1983). Breaking out: feminist consciousness and feminist research. London: Routledge and Kegan Paul.

Stanley, L., \& Wise, S. (1993). Breaking out again: feminist ontology and epistemology. London: Routledge.

Stewart, J. (2006). Transformational leadership: an evolving concept examined through the works of Burns, Bass, Avolio, and Leithwood. Canadian Journal of Educational Administration and Policy, 54: 1-29.

Winston, B. E., \& Patterson, K. (2006). An integrative definition of leadership. International Journal of Leadership Studies, 1(2): 6-66. 